http://dx.doi.org/10.12775/szhf.2019.004

\author{
ZBigniew DrozdowicZ \\ Uniwersytet im. Adama Mickiewicza w Poznaniu, Polska \\ ORCID: 0000-0001-9409-9029 \\ E-MAIL: DROZD@AMU.EDU.PL
}

\title{
Raz jeszcze o kartezjańskim przełomie filozoficznym
}

\section{Kilka ujęć kartezjańskiego przełomu}

Lista tych ujęć jest tak mocno zróżnicowana, że wymaga znalezienia takiego wspólnego mianownika, który wprowadzałby do niej jakieś uporządkowanie. Takim mianownikiem może być to, czy przełom ten jest oceniany pozytywnie, czy też negatywnie i ewentualnie dlaczego jest oceniany tak, a nie inaczej. Problem jednak w tym, że jego postrzeganie i przedstawienie wyłącznie w kolorach czarno-białych stanowi niejednokrotnie mniej lub bardziej świadome uproszczenie filozofii kartezjańskiej, pomijające istotne jej cechy. Takim mianownikiem może być również wpisanie tej filozofii w szerszą tradycję oraz jej konfrontowanie zarówno z tymi poglądami, które były jej stosunkowo bliskie, jak i z tymi, z którymi nie chciała ona mieć nic wspólnego. W tym przypadku trudność polega nie tylko na tym, że nie zawsze chcieć to móc - nawet dla takiego filozofa jak Kartezjusz. Niejedna z jego opozycji nie była bowiem tak radykalna, aby można ją było uznać za całkowite zerwanie 
z określoną tradycją czy też - posługując się Kartezjańskim określeniem uznać, że buduje on całkowicie „na własnym gruncie”. Jeszcze innym kluczem może być konfrontowanie jego filozofii nie z poglądami innych filozofów, lecz z osiągnięciami poszczególnych nauk. Tutaj również możliwych jest wiele wariantów i w każdym przypadku wybór jednych nauk, a pominięcie innych wymaga gruntowniejszego uzasadnienia. W tej części rozważań przywołam takie ujęcia kartezjańskiego przełomu, których wprawdzie nie można sprowadzić do wspólnego mianownika, jednak można o nich powiedzieć, że w jakiejś mierze ilustrują skalę występujących w tym zakresie możliwości.

Zacznę od ujmowania kartezjańskiego przełomu filozoficznego przez Edmunda Husserla. Ma ono jednak dwie istotnie różnice się wersje. Pierwsza z nich pojawiła się w wygłoszonych w lutym 1929 roku w paryskiej Sorbonie wykładach; został one opublikowane w 1931 roku w formie rozprawy pt. Medytacje kartezjańskie. We wstępie do niej Husserl swoją własną filozofię określa mianem neokartezjanizmu. Jest to jednak taki neokartezjanizm, który „na drodze radykalnego rozwijania kartezjańskich motywów - zmuszony jest odrzucać niemal całą rozpowszechnioną teoretyczną zawartość filozofii kartezjańskiej" ${ }^{1}$. Coś istotnego jednak z niej Husserl pozostawia w swojej filozofii, którą określa mianem fenomenologii trascendentalnej. Dotyczy to tak fundamentalnych dla Kartezjusza oraz idącego za jego wskazaniami Husserla kwestii jak: 1. „pragnienie całkowitego i ostatecznie ugruntowanego rozumienia” samego siebie oraz swojego bliższego i dalszego otoczenia; 2. „cofnięcie się do siebie samego i podjęcie próby zdobycia się w sobie samym na obalenie wszystkich obowiązujących dotąd nauk i zbudowania ich na nowo"; 3. "powrót do ego czystych cogitationes”; czy też 4. wykluczenie na drodze „metodycznej krytyki tego wszystkiego, co w naturalnym życiu doświadczenia i myślenia pewne" lub też - co w gruncie rzeczy na to samo wychodzi „wykluczenie wszystkiego, co pozostawia miejsce na możliwość wątpienia”. Wszystko to oznacza, że „Kartezjusz inauguruje całkiem nowy typ filozofowania, filozofowania, które zmieniając cały dotychczasowy styl, odwraca się w radykalny sposób od naiwnego obiektywizmu i [zwraca - Z.D.] w kierunku

${ }^{1}$ Por. Edmund Husserl, Medytacje kartezjańskie, przeł. Andrzej Wajs (Warszawa: PWN, 1982), 1 i n. 
subiektywizmu transcendentalnego". To właśnie ma w rozumieniu Husserla stanowić istotę kartezjańskiego przełomu.

Inaczej przedstawia Husserl kwestię kartezjańskiego przełomu w cyklu wykładów na temat kryzysu nauk europejskich wygłoszonym w 1936 roku na praskim uniwersytecie: przede wszystkim umieszczony jest on w innym kontekście problemowym. Stanowi go ów tytułowy kryzys nauk europejskich, łączony przez Husserla z podejmowanymi, począwszy od drugiej połowy XIX stulecia, próbami „pozytywistycznej reedukacji idei nauki do nauki o samych faktach” "Zdaniem tego filozofa oznacza to „obojętne odwrócenie się od pytań, które dla autentycznej ludzkości są pytaniami rozstrzygającymi” takich m.in. jak pytania: „o sens lub bezsens całego ludzkiego życia” czy też o to, czy człowiek jest, czy może nie jest „wolny w swych możliwościach rozumnego kształtowania siebie samego i swego otoczenia", oraz czy możemy, czy też nie możemy „żyć w takim świecie, w którym wydarzenia historyczne nie są niczym innym jak tylko jakimś nieustannym splotem iluzorycznych wzlotów i gorzkich rozczarowań". Te i podobne im pytania pojawiły się już w filozofii starożytnej, a później powrócono do nich w odrodzeniu, jednak nie w jakimś „oklepanym szkolnym pojęciu”, lecz w „uzasadnieniu autonomii ludzkości europejskiej przez nową koncepcję idei filozofii”, tj. takiej, która jest „nauką wszechobejmującą”, natomiast poszczególne dyscypliny naukowe „są jedynie niesamodzielnymi odgałęzieniami Jednej Filozofii”’.

Do takiego pojmowania filozofii oraz poszczególnych dyscyplin naukowych $\mathrm{w}$ epoce odrodzenia przyczynili się w szczególności tacy uczeni jak Galileusz (zaproponował swoistą „matematyzację przyrody” oraz „drogę myślową, która do niej prowadziła"), natomiast w czasach nowożytnych m.in.: Baruch Spinoza, David Hume i Immanuel Kant. Szczególnie znaczący w dokonaniu tego przełomu był jednak udział Kartezjusza. Zdaniem Husserla był on głównym „twórcą zarówno nowożytnej idei obiektywistycznego racjonalizmu, jak i rozsadzającego go motywu transcendentalnego". Stało się tak za sprawą jego „Zwrotu ku ego cogito” oraz „kartezjańskiej époche”, która

\footnotetext{
${ }^{2}$ Por. Edmund Husserl, Kryzys nauk europejskich, przeł. Sławomira Walczewska (Toruń: Wydawnictwo Rolewski, 1999), 7 i n.

${ }^{3}$ „Gdy je dokładnie rozpatrzyć, okazuje się, że [...] posiadają one swą nierozerwalną jedność w tym, że zawierają one w sobie (wprost lub w sposób implikowany przez swój sens) zagadnienia rozumu, rozumu w jego wszystkich szczegółowych postaciach”, (tamże, 10).
} 
„jest rzeczywiście époche o niesłychanym dotąd radykalizmie, gdyż obejmuje wyraźnie nie tylko ważność wszelkich dotychczasowych nauk (nie pomijając nawet matematyki, pretendującej do apodyktycznej oczywistości, lecz także ważność przed- i pozanaukowego świata przeżywanego, a zatem świata doświadczenia zmysłowego i całego karmiącego się nim życia myśli, przednaukowego, a wreszcie także i naukowego - świata, który pierwotnie dany jest stale jako samo przez się zrozumiały, w sposób nie budzący wątpliwości"4. Jest to $\mathrm{w}$ niektórych punktach zbieżne $\mathrm{z}$ tym przedstawieniem kartezjańskiego przełomu, które pojawia się na kartach Medytacji kartezjańskich. Jednak tylko w niektórych punktach, jasno bowiem wynika z tego ujęcia, że przełom ten miał swoich prekursorów w epoce odrodzenia.

Za przełomowe uznał Kartezjańskie myślenie o człowieku również Antonio Damasio, portugalski kognitywista specjalizujący się w neurobiologicznych i neurologicznych badaniach mózgu. Uznał je za rewolucyjne, ale też zasadniczo błędne i - co gorsza - wpływające negatywnie na pojmowanie relacji między trzema bytami, tj. emocjami, rozumem oraz mózgiem. W książce pod wielce wymownym tytułem - Błąd Kartezjusza - wychodzi on od stwierdzenia, że ,już we wczesnym dzieciństwie uczono go, że właściwe decyzje podejmuje się z chłodnym wyrachowaniem, a emocje i rozsądek nie mieszają się ze sobą, podobnie jak woda i olej”’ W Walszej części zawartych w niej wywodów Damasio stara się „pokazać, iż rozum nie jest tak nieskażony, jak większość z nas to sobie wyobraża lub tego sobie życzy, a emocje i uczucia nie muszą być wcale traktowane jako wdzierający się do jego bastionu intruzi”. W końcowych partiach książki jej autor podejmuje próbę precyzyjnego określenia: „na czym polegał ten błąd Kartezjusza?” zresztą nie jedyny, gdyż „można go również skarcić za to, że przekonał biologów, by uznali mechanizm zegara za model procesów życiowych”. To jednak okazuje się nie tak ważne jak kartezjańskie „wyobrażenie sobie myślenia jako aktywności całkowicie odseparowanej od ciała i wprowadzenie podziału na "rzecz myślącą" (res cogitans), oraz oddzielenie od niej "niemyślącego ciała«, które jest pewnym rozszerzeniem lub sterowanym przez nią mechanizmem

\footnotetext{
${ }^{4}$ Tamże, 81 i n.

${ }^{5}$ „Rosłem w przekonaniu, że rozum rezyduje w jakiejś wydzielonej części mózgu, do której uczucia nie powinny mieć dostępu”. Por. Antonio Damasio, Błąd Kartezjusza. Emocje, rozum i ludzki mózg, przeł. Maciej Karpiński (Poznań: Wydawnictwo Rebis, 2011), 9 i n.
} 
(res extensa)"․ Pewną okolicznością łagodzącą dla Kartezjusza może być to, że podobny błąd popełniali przed nim inni filozofowie. Natomiast argumentem przemawiającym przeciwko niemu jest to, że później „wiele jego tez pozostawało i pozostaje nadal tak oczywistych, że nie wymaga ponownego rozważenia”. Warto przypomnieć, że na ten „błąd Kartezjusza” wskazywali już jego współcześni - tacy m.in. jak autor Zarzutów piątych do Medytacji Pierre Gassendi ${ }^{8}$. Odpowiedź Kartezjusza na te zarzuty przekonuje, że nie tylko miał on swoje racje, ale także nie chciał on lub nie potrafił uznać trafności racji przeciwnych - co oczywiście stanowi pewną cenę za wiarę we własne możliwości poznawcze, demonstrowaną przez filozofa.

Ważne głosy w sprawie kartezjańskiego przełomu pojawiają się również w zbiorze artykułów poświęconych dokonaniom tego filozofa i uczonego pt. The Cambridge Companion to Descartes. We wprowadzeniu redaktor naukowy tomu John Cottingham wskazuje, że ważnym osiągnięciem Kartezjusza było m.in. „wygenerowanie takiego modelu wiedzy i rozumowań”, które sprawiły, że zyskał miano ojca nowożytnej filozofii ${ }^{9}$. Częściami składowymi tego modelu są nie tylko kartezjańska formuła: cogito ergo sum (zdaniem Cottinghama "najsłynniejsze filozoficzne powiedzenie wszechczasów”), ale także po pierwsze, uznanie, „konieczności zrekonstruowania wiedzy od zera” (pomysł całkowicie rewolucyjny, ale rewolucja ta - jak zresztą każda inna -

${ }^{6}$ „Oto i błąd Kartezjusza: oddzielenie otchłanią ciała i umysłu, uchwytnego, mierzalnego, działającego na podstawie jakiegoś mechanizmu, nieskończenie podzielnego ciała oraz nieuchwytnego, niemierzalnego, niedotykalnego i niepodzielnego umysłu [...]. W szczególności zaś jego błędem było oddzielenie najbardziej wyrafinowanych operacji umysłowych od struktury i funkcjonowania organizmu biologicznego" (tamże, 274).

7 „Coś z kartezjańskiego dualizmu stoi też zapewne za poglądami neurologów, którzy twierdzą, że naturę umysłu można w pełni wyjaśnić tylko w terminach tego, co rozgrywa się w mózgu, nie biorąc pod uwagę wpływu całej reszty organizmu ani jego fizycznego i społecznego otoczenia [...]" (tamże, 275).

${ }^{8}$ Por. Pierre Gassendi, „Zarzuty piąte”, w: René Descartes, Medytacje i pierwszej filozofii, przeł. Maria i Kazimierz Ajdukiewiczowie (Kęty: Wydawnictwo Antyk, 2001), 217.

${ }_{9}$ „[...] nie w tym sensie, że obecnie podążamy za jego systemem; bardziej interesujące jest to, że bez filozofii Kartezjusza charakter problemów, z którymi się ciągle borykamy, a które dotyczą wiedzy i nauki, subiektywności i obiektywnej rzeczywistości, materii i świadomości, byłby zupełnie inny". Por. John Cottingham, "Introduction", in: The Cambridge Companion to Descartes (New York-Melbourne-Madrid-Cape Town-Singapore-Sao Paulo: Cambridge University Press 2005). 
nie została „porządnie i do końca przeprowadzona”), oraz po drugie, przyjęcie takiej strategii postępowania w swoim myśleniu i prezentowaniu jego wyników, która pozwoliłaby uniknąć konfliktów z doktrynami scholastycznymi. Są to tylko niektóre elementy filozofii Kartezjusza. Do nich jednak nie ogranicza się kartezjański przełom, ma on bowiem również swoje znaczące formy wyrazu w naukach szczegółowych - takich m.in. jak matematyka (traktowana przez tego filozofa jak taka „nauka powszechna, która wyjaśnia wszystko, bez względu na materię przedmiotu”), fizyka („najważniejszą cechą kartezjańskiej fizyki było odrzucenie przez nią sił i cech nadprzyrodzonych oraz przedstawienie programu "matematyzacji« fizyki”) czy fizjologia, psychologia i etyka (w swoich Namiętnościach duszy Kartezjusz „przechodzi od fizjologii i psychologii do etyki, którą przewidział jako jedną z ostatnich nauk wypływających z jego filozoficznego systemu" ${ }^{\prime 10}$ ).

Zarówno redaktor naukowy tego zbioru, jak i jego współautorzy przyznają, że nie wszystko to, co Kartezjusz głosił, było trafne lub przynajmniej trafniejsze niż to, co twierdzili jego oponenci i konkurenci do filozoficznej oraz naukowej sławy. Co więcej, niejeden ze współczesnych filozofów „zajmujących się czy to teorią poznania, czy filozofią umysłu skłonny jest zdefiniować swoje stanowisko jako anty-kartezjańskie”. Niejedna też z jego tez „kosmologicznych i astronomicznych nie jest dzisiaj niczym więcej niż historycznymi ciekawostkami”, a rozwój nauk fizycznych sprawił, że wyniki badań Kartezjusza $\mathrm{w}$ tym zakresie są przestarzałe, a niektóre z nich (jak np. wyjaśnienia dotyczące zjawiska grawitacji) wręcz naiwne. Nie oznacza to jednak, że w swoim czasie nie miały one nowatorskiego, a niektóre z nich wręcz przełomowego charakteru.

\footnotetext{
${ }^{10}$ „[...] satysfakcja ze spełnionego obowiązku, zdrowego i zadowalającego trybu życia byłaby jednym z owoców prawidłowego naukowego rozumowania w kwestii mechanizmów ciała i ich związków z umysłem. Emocje i uczucia pojawiające się w wyniku mieszania się tego, co umysłowe, z tym, co cielesne, stanowią dla Kartezjusza jeden z zasadniczych składników dobrego życia i są odpowiedzialne za rozwijanie tych nawyków myślowych i zachowań, za pomocą których namiętności mogą być kontrolowane i odpowiednio kierowane [...]” (tamże, 16).
} 


\section{Kartezjański intelektualizm}

Na temat kartezjańskiego intelektualizmu wypowiadałem się już wielokrotnie, przy różnych okazjach, oraz przedstawiałem go w różnych ujęciach zarówno cząstkowych, jak i całościowych ${ }^{11}$. Czasami starałem się wykazać, że miał on - wbrew temu, co sądził sam Kartezjusz - swoich poprzedników (np. Platona) oraz swoich kontynuatorów - m.in. Spinozę czy Kanta, którzy wprowadzali do niego istotne korekty i proponowali w ich przekonaniu jego lepsze wersje. W takim pojmowaniu i prezentowaniu kartezjańskiego intelektualizmu nie jestem ani odosobniony, ani też specjalnie oryginalny. Niejeden ze znawców filozoficznej tradycji wskazywał już bowiem przede mną na jego występowanie u tego i nie tylko tego filozofa. Przykładem może być zarówno przywoływany już tutaj Husserl, jak i nieprzywoływany wcześniej Alistair MacIntyre ${ }^{12}$. W licznych z proponowanych przez moich poprzedników ujęciach tego intelektualizmu znajduję inspirację do swojego odczytywania filozofii Kartezjusza i poszukiwania w niej elementów głębokiego przełomu. Niemniej przełom ten miał wieloaspektowy charakter i w zależności od tego, który z nich będziemy brali pod uwagę, może on być przedstawiany i oceniany w znacząco różniący się sposób. Co więcej, w każdym przypadku istotne znaczenie ma przy tym nie tylko to, co sam Kartezjusz przyjmował i proponował, ale także to, z jakich założeń światopoglądowych i filozoficznych wychodzili ci, którzy odwoływali się i odwołują do tego filozofa. Jest to oczywiste. Jednak ta oczywistość - jak zresztą wiele innych - stawia takie znaki zapytania, które sprawiają, że nie wszystko może tutaj być jasne lub - co w gruncie rzeczy na to samo wychodzi - pozostawia możliwość zgłaszania różnego rodzaju wątpliwości.

\footnotetext{
${ }^{11}$ Por. m.in. Zbigniew Drozdowicz, Kartezjański racjonalizm. Zrozumieć Kartezjusza (Poznań: Wydawnictwo Fundacji Humaniora, 2014).

${ }^{12}$ Zdaniem A. MacIntyre’a Kartezjusz w istotnym stopniu przyczynił się do wiary w możliwość znalezienia przez ludzki rozum i kierowania się nimi w filozoficznym myśleniu tzw. pierwszych zasad - zasad, które później „długo straszyły w empiryzmie”. Por. Alistaire MacIntyre, Dziedzictwo cnoty. Studium z teorii moralności, przeł. Adam Chmielewski (Warszawa: PWN, 1996), 472.
} 
Wyjdę zatem od nieco uważniejszego przyjrzenia się tej oczywistości, która stanowi część integralną każdego intelektualizmu, w tym intelektualizmu kartezjańskiego. Była ona zresztą dosyć szczegółowo analizowana przez Husserla np. w jego Medytacjach kartezjańskich. Nie będę jednak przywoływał całej tej analizy, przypomnę jedynie jej wynik: sprowadza się on do stwierdzenia, że oczywistość ta nie była na tyle doskonała, aby całkowicie wyeliminować „niejasność i niewyraźność w samoprezentacji rzeczy względnie stanów rzeczy”, a bez ich wyeliminowania nie ma i być nie może „absolutnej pewności lub, co na jedno wychodzi, absolutnej niepowątpiewalności"13. Generalnie podzielam tę opinię Husserla. Dla wskazania specyfiki kartezjańskiego przełomu to rozpoznanie jest warunkiem koniecznym, choć niewystarczającym. Trzeba bowiem również odpowiedzieć na pytanie, co warunkuje ową oczywistość i sytuuje ją w tym, a nie w innym miejscu kartezjańskiego systemu filozoficznego oraz co stanowi uzasadnienie dla jej obecności w tym systemie. Nie ulega wątpliwości, że jest to ludzki intelekt, tj. taka władza ludzkiego umysłu, co do której Kartezjusz był całkowicie przekonany, że jest dana wszystkim ludziom. Uzasadnieniem dla tego było przekonanie, że prawdy matematyczne mają charakter konieczny i powszechny. W świetle stanowiska tego filozofa prawdziwą sztuką nie jest posiadanie tej władzy poznawczej, lecz umiejętne korzystanie z jej mocy, a do tego zdolni są już tylko nieliczni. Jest to jasno powiedziane w jego Prawidłach kierowania umysłem $^{14}$. Z kolei w Rozprawie o metodzie jej autor z udawaną skromnością (udawanie to ma jednak swoje logiczne i pragmatyczne uzasadnienie) oświadcza, że należy do nielicznego grona tych, którym udało się „przypadkowo” trafić na właściwą drogę prowadzącą do prawdy i podążać nią tak wytrwale, że przynajmniej do niektórych prawd udało mu się dojśćc ${ }^{15}$. Tej deklaracji nie brałbym jednak dosłownie, bo przecież to nie przypadek może rządzić poczynaniami intelektualisty typu kartezjańskiego. Deklaracja ta ma jednak nie tylko swoje logiczne, ale także pragmatyczne, a nawet psychologiczne uzasadnienie - wskazywałem na nie przy okazji swojej próby całościowego ujęcia kartezjańskiego racjonalizmu.

\footnotetext{
${ }^{13}$ Por. Edmund Husserl, Medytacje kartezjańskie, 20 i n.

${ }^{14}$ Por. René Descartes, Prawidła kierowania umysłem, przeł. Ludwik Chmaj (Warszawa: PWN, 1958).

${ }^{15}$ Por. René Descartes, Rozprawa o metodzie, przeł. Wanda Wojciechowska (Warszawa: PWN, 1970).
} 
To uzasadnienie można znaleźć jednak nie tyle w przywoływanych przez Husserla Medytacjach o pierwszej filozofii, ile w napisanych wcześniej Prawidłach i Rozprawie o metodzie. Ta kolejność czytania kartezjańskich rozpraw ma istotne znaczenie zarówno dla samego zrozumienia systemu filozoficznego tego myśliciela, jak i dla sposobu dochodzenia do niego. Jedno w tym zdaje się bezdyskusyjne: „wszystko, co mogłoby służyć za filozoficzny punkt wyjścia, musimy pozyskać jedynie dzięki samym sobie”. Do tego Husserlowskiego rozpoznania specyfiki medytacji kartezjańskich dopowiem tylko, że owo „samo sobie” przekłada się nie tylko na wiarę w moc poznawczą jednostkowego medytującego intelektu, lecz także na takie uporczywe i konsekwentne analizowanie tego wszystkiego, co można znaleźć w ludzkim myśleniu (cogitare), że na końcu nie pozostaje już nic takiego, co mogłoby dostarczyć jakiejkolwiek racji do wątpienia. Powiedziane to jest jasno i jednoznacznie w początkowych partiach Medytacji I, zatytułowanej: O czym można wątpić? ${ }^{16}$. Rzecz jasna, nie można wątpić w to, co nie dostarcza żadnych do tego racji. Zgodnie ze stanowiskiem Husserla nie jest to jeszcze „przewrót kartezjański”. Dochodzi bowiem do tego wiele innych elementów, m.in.: 1. „wżycie się w naukowe dążenie i naukowe działanie i tym samym uczynienie sobie jasnym i wyraźnym to, co czego one właściwie zmierzają, 2. „dążenie w nich do uniwersalności - niezależnie od tego, jak mają się sprawy faktycznego ich urzeczywistnienia”, 3. „zróżnicowanie oczywistości” i „znajdowanie w sobie pierwszej oczywistości”, oraz 4. rozpoznanie „ego cogito jako transcendentalnej subiektywności”.

I w tym przypadku skłonny jestem zgodzić się ze stanowiskiem Husserla. Jednak nie bez pewnych zastrzeżeń, a przynajmniej nie bez uznania konieczności istotnych dopowiedzeń, $\mathrm{i}$ to $\mathrm{w}$ każdym $\mathrm{z}$ wyróżnionych przez niego punktów. W przypadku pierwszego z nich uzupełnienia dotyczą związków występujących między jasnością i wyraźnością, a także między nimi i oczywistością. Wyjaśnienia tych kwestii można znaleźć zarówno w przywoływanych już tutaj Prawidłach kierowania umysłem, jak i - w skorygowanej wersji - Zasadach filozofii Kartezjusza ${ }^{17}$. Również w tej kwestii wypowiadałem się nie-

\footnotetext{
${ }^{16}$ Por. René Descartes, Medytacje opierwszejfilozofii, przeł. Mariai Kazimierz Ajdukiewiczowie (Kęty: ANTYK, 2001), 42.

${ }^{17}$ Por. René Descartes, Zasady filozofii, przeł. Izydora Dąmbska (Warszawa: PWN, 1960).
} 
jednokrotnie. Zatem tutaj jedynie krótko przypomnę, że jasność i wyraźność zostały uznane przez tego filozofa za oznaki (kryteria) prawdziwości, natomiast oczywistość za oznakę (kryterium) pewności, przy czym w świetle jego przekonań nie może być coś oczywiste, jeśli uprzednio nie będzie jasne i wyraźne. Po krytyce, z którą spotkały się jego Medytacje, Kartezjusz wprowadził istotną korektę do swojego stanowiska. Sprowadzała się ona do zaakceptowania sytuacji, w której wprawdzie możliwe jest osiągnięcie całkowitej jasności w poznaniu intelektualnym, ale nie można uzyskać całkowitej wyraźności. Co więcej, im bardziej odchodzimy od poznania świata wewnętrznego (różnego rodzaju cogitato, coginationes i cogitatum) oraz wkraczamy w poznawanie świata zewnętrznego (rzeczy rozciągłych, ale niemyślących), w tym większym stopniu musimy się liczyć z występowaniem sfery niewyraźności. Wiąże się to bezpośrednio $\mathrm{z}$ drugim $\mathrm{z}$ wymienionych przez Husserla punktów kartezjańskiego przełomu, tj. z dążeniem w poznaniu do uniwersalności. Dążenie to ma jednak istotny związek $\mathrm{z}$ tym, jak się mają ,sprawy jego faktycznego urzeczywistnienia”. O ile bowiem w przypadku świata wewnętrznego można mówić o realnej prawdziwości, tj. wszystkie jego istotne kwestie są faktycznie rozstrzygnięte, to $\mathrm{w}$ przypadku świata zewnętrznego można mówić co najwyżej o potencjalnej prawdziwości, tj. kwestie te mogą być podejmowane i w jakiejś mierze rozstrzygane, ale po pierwsze, w miarę ich pojawiania się, a po drugie, jedynie w jakiejś mierze; a miarę tę wyznaczają nie tylko zdolności, ale także ograniczenia ludzkich władz poznawczych. Zaakceptowanie tej sytuacji uwarunkowane jest nie tylko wiedzą medytującego na sposób kartezjański filozofa i uczonego, ale także jego wiarą, a ponadto związane jest z jego intelektem, wyobraźnią, pamięcią, nastawieniem (intencjonalnością), pragnieniem, a nawet specyficznym sumieniem, które może udzielić takiego przyzwolenia, jakie nie jest skłonny mu udzielić jego intelekt. Moje liczne odwołania do stanowiska Husserla oznaczają w tym przypadku m.in., że ze wszystkich przywoływanych wcześniej ujęć kartezjańskiego przełomu jego perspektywa jest mi najbliższa.

Natomiast w największym stopniu skłonny jestem dystansować się od ujmowania kartezjańskiego przełomu przez Antonia Damasia. Rzecz nawet nie tyle w tym, że Kartezjusz nie oddzielał faktycznie tego, co duchowe, od tego, co cielesne, oraz tego, co racjonalne, od tego, co jest emocjonalne, ile w tym, że takie rozdzielenie nie było niczym nowym w kulturze umysłowej świata 
zachodniego. Jego prekursorów można znaleźć w filozofii starożytnej, natomiast kontynuatorów zarówno we wczesnej, jak i później tradycji chrześcijańskiej. Nie sądzę przy tym, aby myśl kartezjańska miała taką moc sprawczą, by mogła wznieść w kwestii rozdzielenia tych światów jakąś nową „barykadę” czy też nową jakość. Jeśli już można mówić o innowacyjności, to związana jest ona $\mathrm{z}$ wpisaniem tego podziału w szerszą strukturę wywodową oraz z podaniem takiego racjonalizującego to wpisanie uzasadnienia, dla którego raczej trudno byłoby znaleźć odpowiednik we wcześniej tradycji filozoficznej. Pozytywów tego rozdzielenia doszukiwałbym się w tym, że faktycznie związane jest ono dosyć ściśle w przyjętymi wcześniej przez Kartezjusza ogólnym założeniami lub też - co na to samo wychodzi - wynika ono z nich logicznie. Natomiast jego negatywów upatrywać należy w tym, że nie można się z niego wycofać na którymś z etapów tego typu rozumowania - pod groźbą popadnięcia w sprzeczności; a dla intelektualisty typu kartezjańskiego stanowi to jedno z najpoważniejszych zagrożeń. Można oczywiście postawić pytanie: czy należy kurczowo trzymać się tego sposobu myślenia i czy nie powinno się dopuszczać prawomocności innego sposobu dochodzenia do prawdy oraz sprawdzania jego wyników? Trzeba wyraźnie powiedzieć, że Kartezjusz całkowicie nie wykluczał takich możliwości. Jednak traktował je jako co najwyżej pomocnicze i w każdym przypadku hierarchicznie podporządkowane myśleniu dedukcyjnemu. Natomiast z podawanych przez Damasia opisów eksperymentów przeprowadzanych przez niego i podobnych mu badawczy, zajmujących się rozpoznawaniem funkcjonowania ludzkich emocji, rozumu i mózgu, jasno wynika, że preferują oni taki sposób dochodzenia do prawdy, w którym rozstrzygającą rolę odgrywają różnego rodzaju eksperymenty. Samo w sobie nie jest to żadnym błędem. Jednak co najmniej dyskusyjne jest towarzyszące temu opowiadaniu się za eksperymentowaniem przekonanie, że każdy, kto nie posługuje się nim, skazany jest na naukową porażkę w zakresie badań nad funkcjonowaniem ludzkiego myślenia.

Jeszcze kilka słów o rozpoznawaniu kartezjańskiego przełomu przez współautorów przywoływanej tutaj monografii pod redakcją Johna Cottinghama. Do jednych z nich jest mi oczywiście bliżej, natomiast do innych dalej. Jednak do każdego z nich miałbym jakieś zastrzeżenia, łącznie z poglądami wyrażanymi przez Cottinghama. Mniejsza o uznanie przez niego formuły: cogito ergo sum za „najsłynniejsze powiedzenie wszechczasów”. Bardziej 
dyskusyjna wydaje mi się jego teza, że Kartezjusz starał się „za wszelką cenę unikać konfliktów z doktrynami scholastycznymi”. Przeczą temu nie tylko jego odpowiedzi na Zarzuty do Medytacji (w szczególności na Zarzuty drugie oraz Zarzuty szóste, autorstwa teologów i matematyków paryskich), ale także jego list otwarty do teologa i rektora Uniwersytetu w Utrechcie Gisbertiusa Voetiusa - nie sądzę, aby nazwanie kogoś „bezwstydnym kłamcą”, oszczercą i głupcem można uznać za chęć uniknięcia konfliktu z osobą uchodzącą wówczas za autorytet $\mathrm{w}$ zakresie doktryn scholastycznych ${ }^{18}$. Z przeprowadzonej i zamieszczonej w dalszej części wspomnianej monografii analizy stosunku Kartezjusza do scholastyki i scholastyków wynika, że był on albo lekceważący albo nawet pogardliwy i - co nie mniej istotne - filozof nawet nie starał się tego ukrywać ${ }^{19}$. Natomiast za szczególnie trafne i warte upowszechnienia uznaję takie chociażby wyniki analiz, do których doszedł Jean-Luc Marion $\mathrm{w}$ artykule pt. Kartezjańska metafizyka i rola prostych natur. Jeden z jego generalizujących wniosków sprowadza się do stwierdzenia, że żadna rzecz ani stan rzeczy nie są proste same w sobie, a o uznaniu czegoś za coś proste lub „prostsze niż...” decydują nasze władze poznawcze, a zwłaszcza ludzki intelekt ${ }^{20}$. Jest to, generalnie rzecz biorąc, zbieżne $\mathrm{z}$ tym, co uznaję za sedno kartezjańskiego przełomu filozoficznego. Muszę jednak dopowiedzieć, że analiza prostych natur stanowi punkt wyjścia, a nie punkt dojścia w kartezjańskich medytacjach, a jej wyniki, jakkolwiek mają charakter znaczący, to nie mogą być uznane za rozstrzygające o znaczeniu tego filozoficznego przełomu.

\footnotetext{
${ }^{18}$ Por. Edmund Husserl, Medytacje kartezjańskie, przeł. Andrzej Wajs (Warszawa: PWN, 1982).

${ }^{19}$ Por. Roger Ariew, „Descartes and scholasticism: the intellectual background to Descartes' thought", in: John Cottingham, The Cambridge Companion to Descartes, $58 \mathrm{i} \mathrm{n.}$

${ }^{20}$ Zdaniem tego znawcy kartezjanizmu Kartezjusz w Prawidle XII swojej rozprawy pt. Prawidła kierowania umystem „przedstawia zupełnie nową ideę prostej natury. Nie jest to jedynie terminologiczną innowacją, lecz jest także zawiłą epistemologiczną rewolucją. Prosta natura ma dwie charakterystyczne cechy: nie jest ani prosta, ani też nie jest naturą. [...] natury są po prostu produktami końcowymi naszej wiedzy”. Por. J-M. Marion, „Cartesian metaphysics and the role of the simple natures", w: tamże, $115 \mathrm{i} \mathrm{n.}$
} 


\section{Bibliografia}

Cottingham John, (ed.). 2005. The Cambridge Companion to Descartes. New York, Melbourne, Madrid, Cape Town, Singapore, Sao Paulo: Cambridge University Press.

Damasio Antonio. 2011. Błąd Kartezjusza. Emocje, rozum i ludzki mózg, przeł. Maciej Karpiński. Poznań: Rebis.

Descartes René. 2001. Medytacje o pierwszej filozofii, przeł. Maria i Kazimierz Ajdukiewiczowie, Stefan Świerzawski, Izydora Dąbska. Kęty: ANTYK.

Descartes René. 1958. Prawidła kierowania umysłem, przeł. Ludwik Chmaj. Warszawa: Państwowe Wydawnictwo Naukowe.

Descartes René. Rozprawa o metodzie, przeł. Wanda Wojciechowska. Warszawa: PWN.

Descartes René. 1960. Zasady filozofii, przeł. Izydora Dąmbska. Warszawa: PWN.

Drozdowicz Zbigniew. 2014. Kartezjański racjonalizm. Zrozumieć Kartezjusza. Poznań: Wydawnictwo Fundacji Humaniora.

Husserl Edmund. 1982. Medytacje kartezjańskie, przeł. Andrzej Wajs. Warszawa: PWN.

Husserl Edmund. 1999. Kryzys nauk europejskich, przeł. Sławomira Walczewska. Toruń: Wydawnictwo Rolewski.

MacIntyre Alisadair. 1996. Dziedzictwo cnoty. Studium z teorii moralności, przeł. Adam Chmielewski. Warszawa: PWN.

\section{Abstract \\ On the Cartesian Philosophical Breakthrough Once Again}

In is unquestionable that Cartesian thinking on man and the world surrounding him constituted a breakthrough in the philosophical tradition whose origins reach back to ancient times. It is, however, debatable what this breakthrough was about and how far it strayed off the path set by Descartes's adversaries. The propositions occuring in this matter claim that much relies here not only on what Descartes had to give, but also what sort of significance is attached to his propositions. In these remarks I will recall some examples of different understandings and presentations of the Cartesian breakthrough. I mean here not just to show how varied the scale of attached significance could be and in fact is, but more to deliver a point of reference for the understanding of the issue proposed by me. Although it does not differ under every circumstance from every existing picture of it, it is closer however to some and further away from others. In other words, in my opinion what belongs to the 
most significant features of the Cartesian breakthrough is putting the whole stake in the wager for the truth on the cognitive force of the human intellect and, what is nonetheless important, faith in the fact that this power of the human mind is capable of dealing with the most complicated issues and that those which it cannot handle are in fact not worth the interest of a Cartesian philosopher.

Key words: Cartesian philosophical breakthroughs; various dimensions and ways of presenting them; Cartesian intellectualism.

\section{Streszczenie}

\section{Raz jeszcze o kartezjańskim przełomie filozoficznym}

Jest kwestią bezdyskusyjną to, że Kartezjańskie myślenie o człowieku i o otaczającym go świecie stanowiło przełom tradycji filozoficznej, której początki sięgają czasów starożytnych. Dyskusyjne jest natomiast to, na czym ten przełom polegał oraz jak daleko odbiegał do tego, co w tych kwestiach mieli do powiedzenia poprzednicy Kartezjusza. Pojawiające się propozycje przekonują, że wiele zależy nie tylko od tego, co Kartezjusz miał do zaproponowania, ale także od tego, jaką miarę przykłada się do jego propozycji. $\mathrm{W}$ tych rozważaniach przywołam kilka przykładów różnego pojmowania i przedstawiania kartezjańskiego przełomu. Chodzi mi przy tym nie tyle o pokazanie, jak różne mogą to być i są miary, ile o dostarczenie punktu odniesienia dla proponowanego przeze mnie rozumienia tego przełomu. Wprawdzie nie pod każdym względem odbiega ono od wszystkich dotychczasowych jego ujęć, jednak do jednych z nich jest mu bliżej, natomiast do innych dalej. Krótko rzecz ujmując: w moim przekonaniu do najistotniejszych cech kartezjańskiego przełomu należy postawienie całej stawki w grze o prawdę na moc poznawczą ludzkiego intelektu oraz co nie mniej istotne - wiara w to, że władza ludzkiego umysłu jest w stanie poradzić sobie z najtrudniejszymi problemami, a te, których nie jest w stanie rozwiązać, nie są $\mathrm{w}$ gruncie rzeczy warte zainteresowania filozofa typu kartezjańskiego.

Słowa kluczowe: kartezjański przełom filozoficzne; różne jego wymiary i sposoby przedstawiania; kartezjański intelektualizm. 